\title{
PREVALENCE OF TOXOPLASMOSIS IN PIGS IN THE REgION OF SOUTH BOHEMIA
}

\author{
K. HEJLÍČEK and I. LITERÁK \\ Department of Epizootiology \\ University of Veterinary and Pharmaceutical Sciences, 61242 Brno
}

Received May 25, 1992

\begin{abstract}
Hejlíček K. and I. Literák: Prevalence of Toxoplasmosis in Pigs in the Region of South Bohemia. Acta vet., Brno, 62, 1993: 159-166.

The occurrence of antibodies against Toxoplasma gondii and of $T$. gondii itself were monitored in pigs in the district of Strakonice in South Bohemia (Czech Republic) during 1979-1990.

A total number of 2,635 slaughter pigs were examined. The antibodies were found in $5.9 \%$ out of 2,616 samples by Sabin-Feldman test (SFT, titre $\geq 4$ ), in $0.3 \%$ out of 1,179 samples by complement fixation test (CFT, titre $\geq 10$ ), and in $0.1 \%$ out of 2,306 samples by microprecipitation in agar gel (MPA). T. gondii was demonstrated in $1.6 \%$ out of the total number of 2,447 examined animals.

Altogether 57 pigs, which were slaughtered out of the slaughterhouse, were examined, and the antibodies were found in $35.1 \%$ (SFT), and $14.0 \%$ (CFT). T. gondii was detected in $10.2 \%$ of the pigs. Samples of blood serum were examined in 230 pigs in 10 small-scale farms. The antibodies were detected in $30.9 \%$ (SFT; out of 230 examined animals), in $9.5 \%$ (CFT; out of 158 examined animals), and in $0.5 \%$ (MPA; out of 202 examined animals).

Most positive cases were found both by serological tests and by the isolation of the parasite in the pigs from small-scale farms. There were smaller numbers of positive cases from the large-scale farms with old technology, and the lowest number of positive cases was found in the pigs from modern large-scale farms.
\end{abstract}

Pigs, Toxoplasma gondii, antibodies, isolation, small-scale farms, large-scale farm

The information on the occurrence of toxoplasmosis in pigs was compiled in the monograph by Dubey and Beattie (1988). The authors explained the differences they had found among the countries by various animal husbandry practices and by different serological and isolation methods used for the detection of Toxoplasma gondii.

The information on toxoplasmosis in pigs in the territory of the Czech Republic was summarized by Kouba et al. (1974) for the period of 1948 to 1970 . The antibodies were found in $37.5 \%$ of pigs by SFT, in $41.9 \%$ of pigs by CFT, and in $10.7 \%$ of pigs by MPA. T. gondii was isolated from $30 \%$ of pigs. According to later results from the Central State Veterinary Institute in Prague (Zástěra and Pejše 1980; Zástěra et al. 1981, 1983, 1984, 1985, 1986, 1987; Zástěra and Pejšová 1988; Zástěra et al. 1989a, 1989b) the serological prevalence in pigs was $8.8 \%$ (SFT) and T. gondii was isolated from $3.4 \%$ of pigs during 1979 to 1988.

The pig is regarded as relatively susceptible to toxoplasmosis. This was demonstrated by some results of experimental infections (Beverley and Henry 1978; Kan 1970: Ito et al., 1974; Dubey et al. 1984). T. gondii was found in pig tissues by Dubey (1988) as long as 875 days after the experimental infection. Toxoplasmosis in pigs is mostly latent, however, there are also clinical cases described after a spontaneous infection (Sasaki et al. 1976; Koh et al. 1978). The main source of infection for the pig is the domestic cat, in the faeces of which there are large quantities of the oocysts of $T$. gondii. This way the environment, where the pigs are kept, is contaminated together with animal feed or drinking water. The pig can be also infected as a result of canibalism or feeding on infected rodents (Dubey et al. 1986; Weinman and Chandler 1954). 
The occurrence and prevalence of toxoplasmosis in pig farms are affected by various influences. There were repeated observations of the increased percentage of serologically positive animals at older age (Hellesnes et al. 1978; Sasaki et al. 1976; S mith et al. 1992). The antibodies were found more frequently in breeding pigs than in fattened pigs (Dubey et al. 1991). The pigs infected with $T$. gondii were also found more frequently in smaller farms (Rózsa and Matyi 1985; Hellesnes et al. 1978; Zimmerman et al. 1990). The lower percentage of serologically positive animals occurred in well-isolated farms in comparison to the farms with less strict operation routine (Dreesen and Lubroth 1981; Zimmerman et al. 1990; Smith et al. 1992). Manuel and Tubongbanua (1977) found in the Philippines higher percentage of serologically positive pigs in indigenous breeds compared to purebred pigs or crossbreds. Hellesnes et al. (1978) found in Norway higher percentage of serologically positive animals near to the seashore compared to the inland parts of the country. Quehenberger et al. (1990) in Austria and Dubey et al. (1991) in USA found different percentages of serologically positive animals in different regions. On the other hand, there were no seasonal variations during the year (Hellesnes et al. 1978; Zimmerman et al. 1990). Vasconcelos et al. (1979) found no differences in the percentage of serologically positive animals with regard to the age, breed, or sex.

The aim of our study was to learn the present epizootiological situation concerning toxoplasmosis in pigs during a longer time period, and to assess its epidemiological and hygienic importance and some factors that influence the occurrence and prevalence of this infection.

\section{Materials and Methods}

The following examinations were carried out in the district of Strakonice in South Bohemia during the period of 1979 to 1990 :

1. 10 to 25 pigs were sampled at a slaughterhouse approximately in the intervals of one month during the whole year (during the period of 1979 to 1990). The following samples were collected: blood, brain, and muscle tissue of the crura diaphragmatica. The samples were collected in the pigs having the slaughter weight. The pigs had been housed at various farms with old type technology. Moreover, slaughter pigs and culled pigs from a large-scale operation K. (district Strakonice) were sampled as well.

2. In order to make a comparison, the same samples were collected from pigs slaughtered out of the slaughterhouse in 18 villages of the same district during 1988-1989.

3. Blood was collected (usually repeatedly) from pigs at 4 small-scale farms during $1981-1984$, and again at another 6 small-scale farms during 1986-1990. The samples were collected in spring (April), summer (July), autumn (October) and winter (January).

The collected blood samples were conventionally processed to obtain blood serum, which was further examined to demonstrate the antibodies against $T$. gondii. The examinations were carried out by means of Sabin-Feldman test (SFT), microprecipitation in agar gel (MPA), and in the part of the cases also complement fixation test (CFT). SFT was performed according to the standard guidelines of the Central Veterinary Institute in Prague, Czech Republic. CFT was performed according to the standard guidelines of the Ministry of Health of the Czech Republic The biopreparations of ÚSOL, Prague, Czech Republic, were used (SEVATEST Toxoplasma Antigen CFT, SEVATEST Toxoplasma Complement). The basic dilution of serum for SFT was $1: 4$, for CFT $1: 10$. These titres were considered as positive. MPA was carried out with the use of the kits of USOL, Prague, Czech Republic (SEVATEST Toxoplasma Set MPA) according to the respective instructions.

The experiments for the isolation of $T$. gondii were performed as follows: The different tissue samples of the same animal were mixed together as one sample by an electric mixer. A fine suspension in the buffered physiological saline with antibiotics $(600,000 \mathrm{i}$. u. of penicillin $\mathrm{G}$, and $1 \mathrm{~g}$ of streptomycin per $1,000 \mathrm{~cm}^{3}$ ) was obtained. Each sample was used for the administration of $1 \mathrm{~cm}^{3}$ intraperitoneally to two toxoplasma negative mice. The mice were killed after 5 weeks, if they did not die spontaneously earlier. The mice were exsanguinated, and examined microscopically (compressed mounts of brain tissue examined for the occurrence of $T$. gondii cysts), and serologically for SFT antibodies.

\section{Results}

1. A total of 2,635 slaughtered pigs was monitored at the slaughterhouse. Of them 2,616 pigs were examined by SFT. Out of this number, 154 animals $(5.9 \%)$ were found positive. The respective numbers for the examinations by 
CFT were 1,179 with 4 positive cases $(0.3 \%)$, and for MPA 2,306 with 2 positive cases $(0.1 \%)$. The isolation experiment (detection of $T$. gondii) was successful in 39 out of 2,447 cases $(1.6 \%)$.

Since 1981, the slaughter pigs were distinguished with regard to their origin (out of the farms with older technology, and out of the large-scale operation in $\mathrm{K}$.). Totally 1,167 slaughter pigs out of the first group were examined (Table 1). The antibodies were demonstrated by SFT in 76 out of 1,153 examined pigs $(6.6 \%)$, by CFT in 4 out of 658 pigs $(0.6 \%)$, and by MPA in 1 out of 1,004 pigs $(0.1 \%)$. The isolation experiment was carried out in 1,066 pigs. T. gondii was demonstrated in 20 animals, i. e. $1.9 \%$. Out of the second group (Table 2., altogether 1,028 slaughter or culled pigs were examined. The antibodies were demonstrated by SFT in 37 out of 1,023 examined pigs (3.6\%). Totally 512 pigs were examined by CFT, and 862 by MPA, with no positive finding in either group. The isolation experiment was positive in 4 cases out of 950, i.e. in $0.4 \%$.

Out of 39 slaughter pigs with positive finding of T. gondii, 38 animals were simultaneously examined by SFT. However, the antibodies were demonstrated only in 20 animals, i.e. in $52.6 \%$. The other 18 pigs ( $47.4 \%$ ) with the positive finding of $T$. gondii lacked specific antibodies against toxoplasmosis.

Table 1

The results of the examination of slaughter pigs for toxoplasmosis (pigs from farms with old technology, district Strakonice) (SFT - Sabin-Feldman test, CFT - complement fixation test, MPA - microprecipitation in agar gel)

\begin{tabular}{|c|c|c|c|c|c|c|c|c|c|c|c|c|c|}
\hline \multirow{2}{*}{$\begin{array}{l}\text { Year } \\
\\
1981 \\
1982 \\
1983 \\
1984 \\
1985 \\
1986 \\
1987 \\
1988 \\
1989 \\
1990\end{array}$} & \multirow{2}{*}{$\begin{array}{c}\begin{array}{c}\text { Number of } \\
\text { examined pigs }\end{array} \\
51 \\
112 \\
120 \\
100 \\
122 \\
125 \\
109 \\
110 \\
174 \\
144\end{array}$} & \multicolumn{3}{|c|}{$\begin{array}{c}\text { SFT }(\geq 1: 4) \\
\text { number }+ \text { ve } \%\end{array}$} & \multicolumn{3}{|c|}{$\underset{\text { number }}{\text { CFT }}(\underset{+v e}{\geq 1: 10)}$} & \multicolumn{3}{|c|}{$\underset{\text { number }+ \text { ve }}{\text { MPA }}$} & \multicolumn{3}{|c|}{$\begin{array}{l}\text { Isolation experiment } \\
\text { number + ve } \%\end{array}$} \\
\hline & & $\begin{array}{r}51 \\
109 \\
120 \\
100 \\
111 \\
125 \\
109 \\
110 \\
174 \\
144\end{array}$ & $\begin{array}{r}0 \\
11 \\
15 \\
9 \\
9 \\
6 \\
2 \\
4 \\
18 \\
2\end{array}$ & \begin{tabular}{r}
\multicolumn{1}{c}{0} \\
10.1 \\
12.5 \\
9.0 \\
8.1 \\
4.8 \\
1.8 \\
3.6 \\
10.4 \\
1.4
\end{tabular} & $\begin{array}{l}125 \\
109 \\
110 \\
174 \\
144\end{array}$ & $\begin{array}{l}0 \\
0 \\
0 \\
3 \\
1\end{array}$ & $\begin{array}{l}0 \\
0 \\
0 \\
1.7 \\
1.2\end{array}$ & $\begin{array}{l}125 \\
109 \\
110 \\
174 \\
144\end{array}$ & $\begin{array}{l}0 \\
0 \\
0 \\
0 \\
0\end{array}$ & $\begin{array}{l}0 \\
0 \\
1.8 \\
0 \\
0 \\
0 \\
0 \\
0 \\
0\end{array}$ & $\begin{array}{r}40 \\
93 \\
117 \\
93 \\
100 \\
119 \\
107 \\
108 \\
161 \\
128\end{array}$ & $\begin{array}{l}0 \\
3 \\
3 \\
1 \\
1 \\
2 \\
0 \\
0 \\
4 \\
6\end{array}$ & $\begin{array}{l}0 \\
3.2 \\
2.6 \\
1.1 \\
1.0 \\
1.7 \\
0 \\
0 \\
1.5 \\
6.7\end{array}$ \\
\hline Total & 1167 & 1153 & 76 & 6.6 & 658 & 4 & 0.6 & 1004 & 1 & 0.1 & 1066 & 20 & 1.9 \\
\hline
\end{tabular}

Table 2

The results of the examination of slaughter pigs for toxoplasmosis (pigs from the large-scale unit $K$., capacity 8,600 animals, 4 buildings, all in - all out system, housing in pens)

\begin{tabular}{|c|c|c|c|c|c|c|c|c|c|c|c|c|c|c|c|c|}
\hline \multirow{2}{*}{$\begin{array}{l}\text { Year } \\
1981 \\
1982 \\
1983 \\
1984 \\
1985 \\
1986 \\
1987 \\
1988 \\
1989 \\
1990\end{array}$} & \multirow{2}{*}{$\begin{array}{c}\begin{array}{c}\text { Number of } \\
\text { examined pigs }\end{array} \\
32 \\
130 \\
102 \\
130 \\
115 \\
120 \\
139 \\
120 \\
84 \\
56\end{array}$} & \multicolumn{4}{|c|}{$\frac{\text { SFT }}{\text { number +ve } \%}$} & \multicolumn{3}{|c|}{$\begin{array}{c}\text { CFT } \\
\text { number + ve }\end{array}$} & $\%$ & \multicolumn{3}{|c|}{$\begin{array}{c}\text { MPA } \\
\text { number +ve }\end{array}$} & $\%$ & \multicolumn{3}{|c|}{$\begin{array}{l}\text { Isolation experiment } \\
\text { number + ve } \%\end{array}$} \\
\hline & & $\begin{array}{r}31 \\
128 \\
102 \\
130 \\
115 \\
120 \\
139 \\
120 \\
82 \\
56\end{array}$ & $\begin{array}{r}0 \\
3 \\
12 \\
4 \\
2 \\
1 \\
2 \\
5 \\
8 \\
-\end{array}$ & $\begin{array}{r}0 \\
2.4 \\
11.8 \\
3.2 \\
1.7 \\
0.8 \\
1.4 \\
4.3 \\
9.7 \\
-\end{array}$ & & $\begin{array}{r}120 \\
139 \\
120 \\
77 \\
56\end{array}$ & $\begin{array}{l}0 \\
0 \\
0 \\
0 \\
0\end{array}$ & $\begin{array}{l}0 \\
0 \\
0 \\
0 \\
0\end{array}$ & & $\begin{array}{r}120 \\
137 \\
120 \\
77 \\
56\end{array}$ & $\begin{array}{l}0 \\
0 \\
0 \\
0 \\
0\end{array}$ & $\begin{array}{l}0 \\
0 \\
0 \\
0 \\
0\end{array}$ & & $\begin{array}{r}26 \\
117 \\
100 \\
127 \\
112 \\
114 \\
117 \\
114 \\
71 \\
52\end{array}$ & $\begin{array}{l}0 \\
0 \\
0 \\
0 \\
0 \\
0 \\
2 \\
0 \\
2 \\
0\end{array}$ & $\begin{array}{l}0 \\
0 \\
0 \\
0 \\
0 \\
0 \\
1.7 \\
0 \\
2.8 \\
0\end{array}$ \\
\hline Total & 1028 & 1023 & 37 & 3.6 & & 512 & 0 & 0 & & 862 & 0 & 0 & & 950 & 4 & 0.4 \\
\hline
\end{tabular}

Explanations see Tab. 1 . 
2. There were 57 pigs examined, which were slaughtered out of the slaughterhouse (household slaughters, Table 3 ). The antibodies were demonstrated by SFT in 20 of these animals (35.1\%), and in 8 animals by CFT (14.0\%). The isolation experiment confirmed the occurrence of $T$. gondii in 5 out of 49 examined pigs $(10.2 \%)$.

Table 3

The results of the examination of slaughter pigs for toxoplasmosis (pigs slaughtered out of slaughterhouse household slaughters)

\begin{tabular}{|c|c|rrr|rrr|rr|r|r|}
\hline Year & $\begin{array}{c}\text { Number of } \\
\text { examined pigs }\end{array}$ & number & $\begin{array}{c}\text { SFT } \\
\text { +ve }\end{array}$ & $\%$ & number & $\begin{array}{c}\text { CFT } \\
\text { +ve }\end{array}$ & $\%$ & \multicolumn{3}{c|}{$\begin{array}{c}\text { Isolation experiment } \\
\text { number }\end{array}$} \\
\hline 1988 & 37 & 37 & 10 & 27.0 & 37 & 3 & 8.1 & 32 & 3 & 9.4 \\
1989 & 20 & 20 & 10 & 50.0 & 20 & 5 & 25.0 & 17 & 2 & 11.8 \\
Total & 57 & 57 & 20 & 35.1 & 57 & 8 & 14.0 & 49 & 5 & 10.2 \\
\hline
\end{tabular}

3. Altogether 230 samples of blood serum were examined from 10 small-scale farms (Tab. 4). The percentage of positive findings was on average $30.9 \%$ by SFT, $9.5 \%$ by CFT, and only one case was positive by MPA $(0.5 \%)$ out of 202 serum only samples.

The percentage of positive findings was higher compared to the slaughter pigs from large-scale farms. Not only the numbers of positive reactions was higher but also the titres (Table 5).

Table 4

The occurrence of the antibodies against toxoplasmosis in pigs in small-scale farms in the district of Strakonice

\begin{tabular}{|c|c|c|c|c|c|c|c|c|}
\hline \multirow[b]{2}{*}{$\begin{array}{r}1 \text { (R., V.) } \\
2 \text { (M., R.) } \\
3 \text { (M., V.) } \\
4 \text { (K., L.) } \\
5 \text { (K., R.) } \\
6 \text { (S., R.) } \\
7 \text { (A., K.) } \\
8 \text { (K., N.) } \\
9 \text { (L., T.) } \\
10 \text { (V., S.) }\end{array}$} & \multirow{2}{*}{$\begin{array}{c}\begin{array}{c}\text { Monitoring } \\
\text { period }\end{array} \\
1981 \\
1981-84 \\
1981-84 \\
1982-84 \\
1986 \\
1986 \\
1986-89 \\
1986-90 \\
1986-90 \\
1986-90\end{array}$} & \multirow{2}{*}{$\begin{array}{c}\begin{array}{c}\text { Number of } \\
\text { examinations }\end{array} \\
1 \\
23 \\
9 \\
27 \\
2 \\
2 \\
9 \\
31 \\
55 \\
71\end{array}$} & \multicolumn{2}{|c|}{$\underset{\text { positive } \%}{\text { SFT }}$} & \multicolumn{2}{|c|}{$\underset{\text { positive } \%}{\text { CFT }}$} & \multicolumn{2}{|c|}{$\underset{\text { positive } \%}{\text { MPA }}$} \\
\hline & & & $\begin{array}{r}1 \\
8 \\
2 \\
9 \\
0 \\
1 \\
4 \\
8 \\
14 \\
24\end{array}$ & $\begin{array}{l}34.8 \\
22.2 \\
33.3 \\
0 \\
44.4 \\
25.8 \\
25.4 \\
33.8\end{array}$ & $\begin{array}{l}0 \\
0 \\
1 \\
2 \\
5 \\
7\end{array}$ & $\begin{array}{l}0 \\
0 \\
11.1 \\
6.4 \\
9.2 \\
11.7\end{array}$ & $\begin{array}{l}0 \\
0 \\
0 \\
1 \\
0 \\
0 \\
0 \\
0 \\
0 \\
0\end{array}$ & $\begin{array}{l}0 \\
0 \\
0 \\
3.7 \\
0 \\
0 \\
0 \\
0 \\
0 \\
0\end{array}$ \\
\hline Total & & 230 & 71 & 30.9 & $15^{*}$ & 9.5 & $1 * *$ & 0.5 \\
\hline
\end{tabular}

* only 158 samples examined

** only 202 samples examined

Table 5

Percentages of antibody titres found by SFT in pigs of different origin

\begin{tabular}{|l|c|c|c|c|c|c|c|c|c|c|}
\hline Origin of pigs & $\begin{array}{c}\text { Number } \\
\text { of positive } \\
\text { samples }\end{array}$ & $\begin{array}{c}4 \\
\%\end{array}$ & $\begin{array}{c}8 \\
\%\end{array}$ & $\begin{array}{c}16 \\
\%\end{array}$ & $\begin{array}{c}32 \\
\%\end{array}$ & $\begin{array}{c}64 \\
\%\end{array}$ & $\begin{array}{c}128 \\
\%\end{array}$ & $\begin{array}{c}256 \\
\%\end{array}$ & $\begin{array}{c}512 \\
\%\end{array}$ & $\begin{array}{c}1024 \\
\%\end{array}$ \\
\hline $\begin{array}{l}\text { Large-scale } \\
\text { farm } \\
\text { Small-scale }\end{array}$ & 154 & 66.2 & 24.7 & 7.1 & 1.9 & - & - & - & - & - \\
\hline
\end{tabular}


The seasonality of the findings was as follows: Spring - totally 58 examinations with 15 positive cases $(25.8 \%$ ), summer - 65 examinations with 19 positive cases $(29.2 \%)$, autumn -53 examinations with 18 positive cases $(34.0 \%$ ), winter - 54 examinations with 19 positive cases $(35.2 \%)$. The results were not significantly different.

\section{Discussion}

The antibodies against toxoplasmosis were demonstrated by SFT in 5.9\% out of 2,616 examined animals within the group of 2,635 slaughter pigs. Compared to the results of the Central Veterinary Institute in Prague, presented by the Surveillance of Anthropozoonoses in the Czech Republic for the period of 1979 to 1989 , the results of our examinations show somewhat lower occurrence $5.9 \%$ vs. $8.7 \%$ ). A similar trend can be recognized in the results of the isolation experiments for $T$. gondii carried on with 2,447 pig tissue samples (1.6\% vs. $3.4 \%$ ). It should be considered, however, that major part of the pigs in our study originated from a modern large-scale operation, where the incidence of the disease was substantially lower. Compared to the results of previous examinations on the territory of Czechoslovakia, as summarized by Kouba et al. (1974) for the period of 1948 to 1970, our findings are substantially less numerous: SFT 5.9\% vs. $37.5 \%$, CFT $0.3 \%$ vs. $41.9 \%$, MPA $0.1 \%$ vs. $10.7 \%$, positive isolation experiment in $13.0 \%$ cases vs. $30 \%$ of serologically positive pigs. The substantial decrease of the incidence of toxoplasmosis during recent 20 to 30 years can be attributed to the improved conditions of pig husbandry, and limited access of domestic cat, which is the source of oocysts of $T$. gondii, to pig farms. The same observations and conclusions were made by Boch and Neurohr for South Germany (1982).

The importance of the system of housing (especially the level of hygiene, system of feeding, and closed access from outside) for the occurrence of toxoplasmosis was clearly shown in the part of the study that dealt with monitoring pigs from farms with different housing systems. The best situation was found in the animals from a modern large-scale fattening unit. The facility was located approximately $2 \mathrm{~km}$ from a village and was completely isolated from the point of view of its operation. Only industrially manufactured feed was used. The percentage of positive cases, found by SFT, was 3.6\%, SFT and MPA were both negative, the biological experiment was positive in $0.4 \%$ of the cases. At the same time, however, the turnover of the herd was open. The piglets were purchased from other farms within the district, mostly from farms with older technology. There was a possibility of infection before the animals arrived to the large-scale unit. The situation in slaughter pigs from older types of barns was clearly worse. The percentage of positive cases, found by SFT, was $6.6 \%$, by CFT $0.6 \%$, by MPA $0.1 \%$, and the isolation experiment was positive in $1.9 \%$ of the cases. In this group of animals that came from the older types of farms or from reconstructed barns there was an increased possibility of a direct or indirect contact with domestic cat. At the same time more feedstuffs made on-farm were used, which might be contaminated with toxoplasma oocysts as well. The occurrence of toxoplasmosis was clearly highest in pigs slaughtered out of a slaughterhouse (household slaughters). The domestic cat is kept almost in every household with unlimited access to pigs, and also to animal feed, bedding, and generally to the 
places where pigs are kept. Therefore, the percentage of positive cases in this group by different examination methods, i.e. $35.1 \%$ by SFT, $14.0 \%$ by CFT, and $10.2 \%$ by isolation experiment, was approaching the values presented by Kouba et al. (1974).

Similar results of serological examinations were recorded also in pigs from small-scale farms, i.e. kept in analogous conditions. The percentage of positive cases was $30.9 \%$ by SFT and $9.5 \%$ by CFT, thus corresponding to the results of the serological examination from the group of pigs slaughtered out of a slaughterhouse.

Our results agreed completely with the results on the importance of the size and accessibility of pig farms for the incidence of toxoplasmosis, published by Hellesnes et al. (1978), Dreesen and Lubroth (1981), Rózsa and Matyi (1985), Zimmerman et al. (1990), and Smith et al. (1992). For instance Rózsa and Matyi (1985) found $7.2 \%$ serologically positive pigs in closed large-scale farms, $24.4 \%$ in small fattening units and $37.7 \%$ on small part-time farms. Similarly, Zimmerman et al. (1990) found $1.6 \%$ serologically positive cases in pigs in isolated units, and $5.02 \%$ positive cases with more opently accessible farms. Smith et al. (1992) demonstrated the percentage of serologically positive cases of $2.2 \%$ in sows in closed farms, and $16.7 \%$ in farms without closed access. Similarly to Hellesness et al. (1978) and Zimmerman et al. (1990) we were not able to detect the influence of seasonality to the occurrence of toxoplasmosis in small-scale farms. The conditions there remain apparently the same during the whole year. The occurrence of positive results by SFT was not changing from spring to winter and ranged between 25.9 and $35.2 \%$. There is a certain trend of increasing numbers of positive cases by SFT during the year. However, this can be attributed to the fact that the young animals come to the fattening units mostly in spring and summer. They reach the slaughter weight in autumn and mostly in winter they have a possibility to get into contact with $T$. gondii in the environment and to get infected to a larger extent.

The considerable susceptibility of the pig to T. gondii and the importance of the system of housing resulted not only in a higher percentage of serological reactions in pigs in small-scale farms in comparison to the large-scale units but also in the detected titres. In the pigs from large-scale operations, the basic titre of 4 was found frequently, those of 16 and 36 only rarely. In the pigs from small-scale farms there were much higher titres. In some cases the titres even characterized acute infection or an infection with larger numbers of $T$. gondii.

\section{Výskyt a rozšiření toxoplazmózy u prasat $v$ jihočeské oblasti}

V letech 1979-1990 byl sledován výskyt protilátek proti Toxoplasma gondii i výskyt $T$. gondii u prasat $\mathrm{v}$ jihočeském okrese Strakonice (Čská republika). Bylo vyšetřeno celkem 2635 jatečných prasat. Z 2616 jich mělo protilátky $5,9 \%$ (Sabin-Feldmanův test, SFT, titr $\geq 4$ ), z 1179 mělo protilátky 0,3\% (komplementfixační reakce, KFR, titr $\geqq 10$ ), z 2306 mělo protilátky 0,1\% (mikroprecipitace $\mathrm{v}$ agarovém gelu, MPA). T. gondii byla prokázána u 1,6\% prasat z 2447 vyšetřených.

Při vyšetření 57 prasat $z$ domácích porážek byly protilátky zjištěny u 35,1\% (SFT) a $14,0 \%$ (KFR). T. gondii byla prokázána u 10,2\% prasat. V 10 malochovech byla vyšetřena krevní séra 230 prasat. Protilátky byly zjištěny u 30,9\% 
(SFT) prasat z 230 vyšetřovaných, u 9,5\% ze 158 vyšetřených (KFR) a u $0,5 \%$ (MPA) z 202 vyšetřených.

Sérologická $i$ izolační pozitivita byla nejvyšší u prasat $z$ malochovi̊, nižší u prasat ze starších typů velkochovů a nejnižši u prasat $\mathrm{z}$ moderní velkovýkrmny.

\section{Наличие и распространение токсоплазмоза свиней в Южно-Чешской обпасти}

В 1979 - 1990 гг. проводили исследования наличия антител Toxoplasma gondii и наличия $T$. gondii свиней в южно-чешском районе Страконице (Чешская Республика).

В итоге исследовали 2635 убойных свиней. Из 2616 особей антитела были выявлены у 5,9 \% (тест Сабин-Фельдмана, SFT, титр $\geq 4$ ) из 1179 антитела были установлены у $0,3 \%$ (комплеменфиксационные реакции, $\mathrm{KFR}$, титр $\geq 10$ ) из 2306 антитела установили у 0,1 \% (микропреципитация в агаровом геле, MPA). T. gondii установили у $1,6 \%$ свиней из 2447 исследованных особей.

В ходе исследований 57 свиней, үмерщвленных на дому в частном порядке, антитела были выявлены у $35,1 \%$ (SFT) и $14,0 \%$ [KFR]. T. gondii была выявлена у $10,2 \%$ свиней. На мелких свиноводствах провели исследования кровяной сыворотки 230 свиней. Антитела выявили у 30,9 \% (SFT) свиней из 230 исследованных, у 9,5\% из 158 исследованных (KFR) и у 0,5\% (MPA) из 202 исследуемых свиней.

Серологические и изоляционные позитивные данные были самыми высокими у свиней мелкого свиноводства, более низкими - у свиней крупных ферм старшего типа и самыми низкими - у свиней, содержимых в условиях современного промышленного свиноводства.

\section{References}

BEVERLEY, J. K. A. - HENRY, L.: Experimental toxoplasmosis in young piglets. Res. Veter. Sci., 24, 1978: 139-146

BOCH, J.-NEUROHR, B.: Vorkommen latenter Toxoplasma-Infektionen bei Schweinen in Süddeutschland und deren Nachweis mit IFAT und IHA. Tierärztl. Umsch., 37, 1982: 820 to 826

DREESEN, D. S. - LUBROTH, J. S.: Swine toxoplasmosis. 8th International Symposium of the World Association of Veterinary. Food Hygienists, Dublin, Ireland, 30. 8.-4. 9. 1981

DUBEY, J. P. - MURRELL, K. D. - FAYER, R.: Persistence of encysted Toxoplasma gondii in tissues of pigs fed oocysts. Amer. J. Veter. Res., 45, 1984: 1941-1943

DUBEY, J. P.-MURRELL, K. D.-HANBURY, R. D.-ANDERSON, W. R.-DOBY, P. B. - MILLER, H. O.: Epidemiologic findings on a swine farm with enzootic toxoplasmosis. J. Amer. Veter. Med. Assoc., 189, 1986: 55-56

DUBEY, J. P. - BEATTIE, C. P.: Toxoplasmosis of Animals and Man. CRC Press, Inc. Boca Raton, Florida, 1988

DUBEY, J. P.: Long-term persistence of Toxoplasma gondii in tissues of pigs inoculated with $T$. gondii oocysts and effect of freezing on viability of tissue cysts in pork. Amer. J. Veter. Res., 49, 1988: $910-913$

DUBEY, J. P. - LEIGHTY, J. C. - BEAL, V. C. - ANDERSON, W. R. - ANDREWS, C. D. THULLIEZ, PH.: National seroprevalence of Toxoplasma gondii in pigs. I. Parasitol., 77, 1991: $517-521$

HELLESNES, I.-MOHN, S. F.-MELHUUS, B.: Toxoplasmosa gondii in swine in southeastern Norway. Acta veter. scand., 19, 1978: 574-587. 
ITO, S. - TSUNODA, K.-NISHIKAWA, H.-MATSUI, T.: Pathogenicity for piglets of Toxoplasma oocysta originated from naturaly infected cat. Nat. Inst. Anim. Hlth., 14, 1974: $182-187$

KAN, P. T.: Izučenije eksperimentalnogo toksoplazmoza na suporosnych svinomatkach. Vsesojuznyj naučno-issledovatelskij institut veterinarnoj sanitarii, Moskva, 35, 1970: 454-458

KOH, J. G. W. - LOH, H. - TENG, M. F. - CHEOK, W. C.: Toxoplasmosis in a pig herd. Singapore Veter. J., 2, 1978: 17-22

KOUBA, K. - JÍRA, J.-HƯBNER, J.: Toxoplazmóza. Avicenum, Praha, 1974

MANUEL, M. - TUBONGBANUA, R.: A serological survey on the incidence of toxoplasmosis among slaughtered pigs in Metro Manila. Philipp. J. Veter. Med., 16, 1977: 9-19

QUEHENBERGER, P. - SCHULLER, W.-AWAD-MASALNEH, M.: Untersuchung über das Vorkommen von komplementbindenden Antikörpern gegen Chlamydia psittaci und Toxoplasma gondii beim Schwein in den einzelnen Bundesländern Österreichs. Wien. Tierärztl. Mschr., 77, 1990: 285-290

RÓZSA, J. - MATYI, A.: Kis- es nagyuzemi sertes- es juhallomanyok Toxoplasma-fertozottsege Csongrad megyeben. Magy. állatorv. Lap., 40, 1985: 647-649

SASAKI, S. - IIDA, T. - TSUCHIVA, Y. - OMURA, Y. - USUI, K. - TSUJIOKA, T. SUZUKI, M.: A collective outbreak of toxoplasmosis in swine. J. Jap. Veter. Med. Assoc., 29, 1976: 77-82

SMITH, K. E.-ZIMMERMAN, J. J.-PATTON, S.-BERAN, G. W.-HILL, H. T.: The epidemiology of toxoplasmosis on Iowa swine farms with an emphasis on the roles of freeliving mammals. Veter. Parasitol., 42, 1992: 199-211

VASCONCELOS, O. T. - COSTA, A. J. - ÁVILA, F. A.: Aspectos epidemiologicos da infecao por Toxoplasma gondii em suinos. Cientifica, Brazil, 6, 1979: 83-87

WEINMAN, D. - CHANDLER, A. H.: Toxoplasmosis in swine and rodents. Reciprocal oral infection and potential human hazard. Proc. Soc. Exp. Biol. N. Y., 87, 1954: 211-216

ZÁSTĚRA, M.-PEJŠE, M.: Surveillance toxoplasmózy - 1979. In: Zajíček, D. (ed.): Surverillance zoonóz 1979. SVS - oddělení veterinární osvěty, Pardubice, 1980, 144-155

ZÁSTĚRA, M. - POKORNY̌, J. - PEJŠE, M.: Surveillance toxoplasmózy 1980. In: Zajícek, D. (ed.): Surveilance zoonóz 1980. SVS - oddělení veterinární osvěty, Pardubice, 1981, 124-146

ZÁSTĚRA, M. - POKORNÝ, J.-PEJŠOVA, V.: Surveillance toxoplasmózy 1981. In: Zajíček, D. (ed.): Surveillance zoonóz 1981. Ústav veterinární osvěty, Pardubice, 1983, 138-153

ZÁSTÉRA, M.- POKORNÝ, J. - PEJŠOVÁ, V.: Surveillance toxoplasmózy 1982. In: Zajíček, D. (ed.): Surveillance zoonóz 1982. Ústav veterinární osvěty, Pardubice, 1984, 128-144

ZÁSTÉRA, M.- POKORNÝ, J.-PEJŠOVÁ, V.: Surveillance toxoplasmózy 1983. In: Zajiček, D. (ed.): Surveillance zoonóz 1983. Ústav veterinární osvěty, Pardubice, 1985, 130-152

ZÁSTĚRA, M.-POKORNÝ, J.-PEJŠOVA, V.: Surveillance toxoplasmózy 1984. In: Zajíček, D (ed.): Surveillance zoonóz 1984. Ústav veterinární osvěty, Pardubice, 1986, 135-145

ZÁSTÉRA, M. - POKORNÝ, J.-PEJŠ̉ V̊̃, V.: Surveillance toxoplasmózy 1985. In: Zajíček, D. (ed.): Surveillance zoonóz CSR 1985. Ústav veterinární osvěty, Pardubice, 1987, $170-192$

ZÁSTĚRA, M.-PEJŠOVÅ, V.: Surveillance toxoplasmózy 1986. In: Zajíček, D. (ed.): Surveillance antropozoonóz CSR 1986. Ústav veterinární osvěty, Pardubice, 1988, 159-177

ZÁSTĚRA, M.-POKORNÝ, J.-PEJSOVÁ, V.: Surveillance toxoplasmózy 1987. In: Zajíček, D. (ed.): Surveillance antropozoonóz CSR 1987. Ústav veterinární osvěty, Pardubice, 1989a, $117-135$

ZÁSTĚRA, M.-POKORNÝ, J.-PEJSOYÁ, V.: Surveillance toxoplasmózy 1988. In: Zajíček, D. (ed.): Surveillance zoonóz ČR 1988. Ústav veterinární osvěty, Pardubice, 1989b, $136-153$

ZIMMERMAN, J. J.-DREESEN, D. W.-OWEN, W. J. - BERAN, G. W.: Prevalence of toxoplasmosis in swine from Iowa. J. Amer. Veter. Med. Assoc., 196, 1990: 266 -270 